EXTENDED REPORT

\title{
Role of interleukin-1 $\beta$ in the pathogenesis of diabetic retinopathy
}

\author{
R A Kowluru, S Odenbach
}

Br J Ophthalmol 2004;88:1343-1347. doi: 10.1136/bjo.2003.038133

See end of article for authors' affiliations

......................

Correspondence to: Professor R A Kowluru, Kresge Eye Institute, Wayne State University Detroit, MI 48201, USA; rkowluru@med.wayne.edu

Accepted 1 February 2004
Aim: To examine the role of cytokine interleukin-1 $\beta(\mathrm{IL}-1 \beta)$ in retinal capillary cell death in diabetes. Methods: The effect of glucose on the expression of IL-1 $\beta$ was measured in the bovine retinal endothelial cells. The role of IL-1 $\beta$ in the accelerated endothelial cell loss was determined by investigating the effect of human recombinant IL-1 $\beta$ on their apoptosis in normal and high glucose conditions, and was confirmed using interleukin-1 receptor antagonist (IL-1 ra).

Results: High glucose increased IL-1 $\beta$ expression by $60 \%$ compared with cells incubated in $5 \mathrm{mM}$ glucose $(p<0.05)$. Incubation of cells with IL- $1 \beta$ increased NO levels by about $80 \%$ and activated NF- $\kappa B$ by $40 \%$. In the same cells apoptosis was increased by $70 \%$ and caspase- 3 activity was increased by $40 \%$. Supplementation of IL-1 $\beta$ in $20 \mathrm{mM}$ glucose medium further increased nitric oxide and $\mathrm{NF}-\mathrm{KB}$, and accelerated apoptosis, and addition of IL-1 ra significantly decreased glucose induced abnormalities and apoptosis.

Conclusions: IL-1 $\beta$ accelerates apoptosis of retinal capillary cells via activation of NF- $\kappa B$, and the process is exacerbated in high glucose conditions. These studies suggest a possible role of IL-1 $\beta$ in the development of retinopathy in diabetes, and offer a possible rationale to test IL-1 $\beta$ receptor antagonists to inhibit the development of diabetic retinopathy.
$\mathrm{R}$ tinopathy is the most devastating ocular complication of diabetes. Experimental evidence has suggested that continued hyperglycaemia is the initiating event in the development of retinopathy. A variety of biochemical sequelae of hyperglycaemia have been postulated to contribute to the development of retinopathy, but it has been difficult to show convincingly their causal relation. ${ }^{1-4}$ Recent studies have shown that the pathogenesis of diabetic retinopathy shares similarities with a chronic inflammatory disease. Increased levels of cytokines, including interleukin$1 \beta$ (IL-1 $\beta$ ), IL-6, and IL- 8 are detected in the vitreous fluid of the patients with proliferative diabetic retinopathy, ${ }^{56}$ and in the retina from diabetic rats. ${ }^{7}$ In retinal ischaemia reperfusion injury, the expression of IL- $1 \beta$ is dramatically upregulated in the glial cells, endothelial cells, and neutrophils recruited into the retina. ${ }^{8}$ The abnormalities similar to those observed in retinal ischaemia reperfusion are present in the retina in diabetes, suggesting that this inflammatory cytokine might play an important role in the pathogenesis of diabetic retinopathy. Early in the course of the development of diabetic retinopathy in humans and animals, retinal capillary cells undergo accelerated apoptosis, and this can be seen before any histopathology is yet apparent. ${ }^{9}$ Apoptotic cells themselves can become procoagulant in diabetes, and that itself could create a proinflammatory environment. ${ }^{10}$

IL- $1 \beta$ exerts its effects by inducing expression of many genes whose promoters are regulated through complex interactions with transcription factors such as nuclear factor $\mathrm{NF}-\kappa \mathrm{B}$ and APl. ${ }^{11}{ }^{12}$ Recent studies have shown that NF- $\kappa \mathrm{B}$ activation in retinal pericytes is responsible for their hyperglycaemia induced accelerated loss observed in diabetic retinopathy. ${ }^{13}$ We have shown that the activation of retinal NF- $\mathrm{KB}$ in diabetes is an early event in the development of retinopathy, and NF- $\mathrm{KB}$ remains active when the retinal capillary cell death is accelerating, and histopathology is developing. ${ }^{14}$ However, the involvement of IL- $1 \beta$ in the pathogenesis of diabetic retinopathy remains to be established.
The present study was undertaken to examine the possible role of IL-1 $\beta$ in retinal capillary cell death in diabetes. The expression of IL-1 $\beta$ was measured in the retinal endothelial cells exposed to high glucose, and the role of IL-1 $\beta$ in the accelerated capillary cell loss was determined by investigating the effect of exogenous IL- $1 \beta$ on their apoptosis in normal and high glucose conditions. To confirm the involvement of IL- $1 \beta$ in accelerated apoptosis, the effect of neutralisation of IL- $1 \beta$ by antibody against IL- $1 \beta$ (IL- 1 ab) or by IL- $1 \beta$ receptor antagonist (IL-lra) was also investigated.

\section{METHODS}

\section{Capillary cells}

Endothelial cells were prepared from bovine retina as described earlier. ${ }^{14-17}$ The cells were grown to $80 \%$ confluence in petri dishes coated with $0.1 \%$ gelatin in Dulbecco's Modified Eagle Medium (DMEM) containing 10\% fetal calf serum (heat inactivated), $10 \% \mathrm{Nu}$ serum, heparin $(50 \mu \mathrm{g} / \mathrm{ml})$, endothelial growth supplement $(25 \mu \mathrm{g} / \mathrm{ml})$, and antibiotic/ antimycotic in an environment of $95 \% \mathrm{O}_{2}$ and $5 \% \mathrm{CO}_{2}$. Confluent cells from fourth to seventh passage were split and incubated under normal glucose ( $5 \mathrm{mM}$ glucose) or high glucose $(20 \mathrm{mM}$ glucose) conditions for $1-10$ days in the presence or absence of human recombinant IL-1 $\beta$ (0-10 ng/ ml, R\&D Systems, Minneapolis, MN, USA). Control incubations containing $20 \mathrm{mM}$ mannitol were run simultaneously to rule out the effect of increased osmolarity. Each experiment was repeated with at least three separate cell preparations.

\section{Western blot}

The cells were homogenised in $30 \mathrm{mM}$ Tris-HCl buffer containing $10 \mathrm{mM}$ EGTA, $5 \mathrm{mM}$ EDTA, 1\% Triton X-100, $250 \mathrm{mM}$ sucrose, $1 \mathrm{mM} \mathrm{NaF}, 1 \mathrm{mM}$ phenylmethylsulfonyl fluoride, $15 \mu \mathrm{g} / \mathrm{ml}$ aprotinin, $5 \mu \mathrm{g} / \mathrm{ml}$ leupeptin, $5 \mu \mathrm{g} / \mathrm{ml}$ pepstatin, and $1 \mathrm{mM} \mathrm{Na} \mathrm{VO}_{4}$. The homogenate was

Abbreviations: IL, interleukin; iNOS, inducible nitric oxide synthase; NO, nitric oxide. 
centrifuged at $5000 \times g$ for 5 minutes at $4^{\circ} \mathrm{C}$ to remove cell debris. Protein $(40 \mu \mathrm{g})$ was separated on $8-15 \%$ denaturing polyacrylamide gel, and then transferred to nitrocellulose membranes. The membranes were blocked in the wash buffer ( $10 \mathrm{mM}$ Tris- $\mathrm{HCl}, \mathrm{pH} 7.5,100 \mathrm{mM} \mathrm{NaCl}$, and $0.1 \%$ Tween 20 ) containing $5 \%$ milk, followed by the incubation with a polyclonal antibody against IL-1 $\beta$ (R \& D Systems) at 1:500 dilutions. The membranes were washed three times ( 10 minutes each), and incubated for 1 hour at room temperature with horseradish peroxidase linked antirabbit $\operatorname{IgG}$ (1:2500 dilution; Amersham Biosciences, Amersham, UK), and developed using ECL-Plus western blotting detection kit (Amersham Biosciences). Kaleidoscope prestained molecular weight markers (Bio-Rad Laboratories, Hercules, CA, USA) were run simultaneously on each gel. To ensure equal loading among the lanes the expression of housekeeping protein, $\beta$-actin or GAPDH, was determined. After blotting the membrane for the desired proteins, the membranes were incubated with stripping buffer $(62.5 \mathrm{mM}$ Tris-HCl $\mathrm{pH} 6.8$, $100 \mathrm{mM}$ mercaptoethanol, $2 \%$ sodium dodecyl sulfate) at $50^{\circ} \mathrm{C}$ for 30 minutes, washed and incubated with mouse monoclonal antibody against $\beta$-actin (Sigma Chemicals, St Louis, MO, USA) or GAPDH (Biodesign International, Saco, ME, USA). IgG horseradish peroxidase conjugated antimouse antibody was used as the secondary antibody, and the membranes were developed using ECL-Plus western blotting detection kit. Each sample was analysed in duplicate. ${ }^{14}{ }^{17}$

\section{Nitrite levels}

Nitrite production was measured using Greiss reagent. ${ }^{18} 19$ The absorbance was measured at $540 \mathrm{~nm}$, and the nitrite concentration was calculated from a sodium nitrite standard curve.

\section{NF- $\kappa$ B}

$\mathrm{NF}-\kappa \mathrm{B}$ activation was determined by performing western blots to measure the increased expression of the p65 subunit of NF- $\kappa$ B. ${ }^{14}$ Protein was separated on $10 \%$ denaturing polyacrylamide gels, blotted onto nitrocellulose membrane, and after blocking the membrane was incubated with the antibody against NF- $\kappa B$ (p65; 1:500 dilution; Santa Cruz Biotechnology Inc, Santa Cruz, CA, USA).

\section{Cell death}

Cell death was determined by ELISA using Cell Death Detection ELISA ${ }^{\text {PLUS }}$ kit (Roche Diagnostics, Indianapolis, IN, USA), and confirmed by measuring the enzyme activity of caspase-3.

The relative amounts of mono- and oligonucleosomes generated from the apoptotic cells were quantified using monoclonal antibodies directed against DNA and histones respectively as described by us previously. ${ }^{17}$ The cytoplasmic fraction of the cells was transferred onto a streptavidin coated microtiter plate and incubated for 2 hours at room temperature with a mixture of peroxidase conjugated antiDNA and biotin labelled antihistone. The plate was washed thoroughly, incubated with 2,2'-Azino-di-[3-ethylbenzthiazoline sulfonate] diammonium salt (ABTS, Roche Diagnostics), and absorbance was measured at $405 \mathrm{~nm}$. After separation of the cytoplasmic fraction, the nuclear pellet was suspended in $50 \mathrm{mM}$ sodium phosphate buffer (pH 7.5) containing $2 \mathrm{mM} \mathrm{NaCl}, 0.05 \mathrm{mM} \mathrm{Na}_{2} \mathrm{HPO}_{4}$ (pH 7.5) and sonicated. DNA was measured in this fraction, and apoptosis was normalised to the amount of DNA. ${ }^{13}$

\section{Caspase-3}

Activation of caspase-3 in the retina was determined by measuring the cleavage of fluoregenic substrate specific for caspase-3, N-acetyl-As-Glu-1-Val-asp-7-amino-4 trifluoromethyl coumarin (DEVD-AFC, Biomol Research Laboratories). The fluorescence signal emitted by cleavage of the substrate was quantified at excitation and emission wavelengths of $400 \mathrm{~nm}$ and $505 \mathrm{~nm}$ respectively as routinely used in our laboratory. ${ }^{16}{ }^{17}$ Each sample was measured in duplicate.

\section{Statistical analysis}

Data are reported as mean (standard deviation), and experimental groups were compared using the non-parametric Kruskal-Wallis test followed by Mann-Whitney test for multiple group comparison. Similar conclusions were reached also by using ANOVA with Fisher or Tukey.

\section{RESULTS}

\section{Effect of high glucose on IL- $1 \beta$ expression in retinal} endothelial cells

Incubation of retinal endothelial cells in $20 \mathrm{mM}$ glucose for $3-5$ days resulted in about $60 \%$ increase in the protein expression of IL-1 $\beta$ compared with the cells incubated in $5 \mathrm{mM}$ glucose $(\mathrm{p}<0.05$, fig 1$)$. When the incubation with $20 \mathrm{mM}$ glucose was extended to 10 days the expression of IL$1 \beta$ did not show any additional increase (data not shown). Addition of $20 \mathrm{mM}$ mannitol, instead of glucose, failed to increase IL-1 $\beta$ expression, suggesting that the glucose induced increase in IL-1 $\beta$ was not due to an increase in the osmolarity. Despite the differences in the expression of IL- $1 \beta$, the content of the intrinsic protein, $\beta$-actin or GAPDH did not vary among various lanes. This shows that high glucose results in increased cytokines levels in the retinal endothelial cells.

\section{Effect of IL-1 $\beta$ on nitric oxide and cell death}

The data in figure $2 \mathrm{~A}$ show that the incubation of endothelial cells in $5 \mathrm{mM}$ glucose medium containing $10 \mathrm{ng} / \mathrm{ml} \mathrm{IL-} 1 \beta$ for 3 days resulted in the increase of nitric oxide (NO) by over $80 \%$ compared with that from the cells incubated without IL- $1 \beta$. In the same cells addition of IL- $1 \beta$ resulted in the activation of NF- $\kappa B$, as shown by $40 \%$ increase in the expression of $65 \mathrm{kD}$ subunit of NF- $\mathrm{KB}$ (fig 3 ).

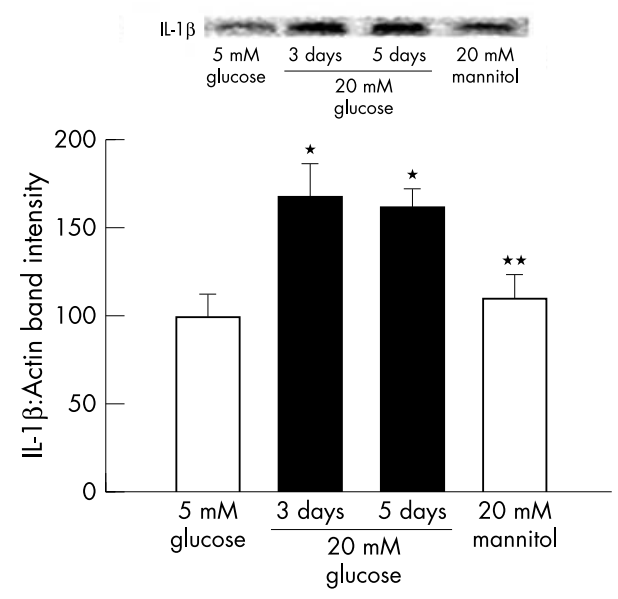

Figure 1 Effect of glucose on the expression of IL-1 $\beta$ in endothelial cells: IL- $1 \beta$ expression was measured by western blot technique in the retinal endothelial cells incubated in $5 \mathrm{mM}$ and $20 \mathrm{mM}$ glucose medium for 3-5 days. Each measurement was performed in duplicate using three different cell preparations. The histogram represents the absorbance of IL-1 $\beta$ band adjusted to the expression of the intrinsic protein in each lane. The values obtained at $5 \mathrm{mM}$ glucose are considered $100 \%$. ${ }^{*} p<0.05$ and ${ }^{* *} p<0.05$ compared with $5 \mathrm{mM}$ and $20 \mathrm{mM}$ glucose respectively. 

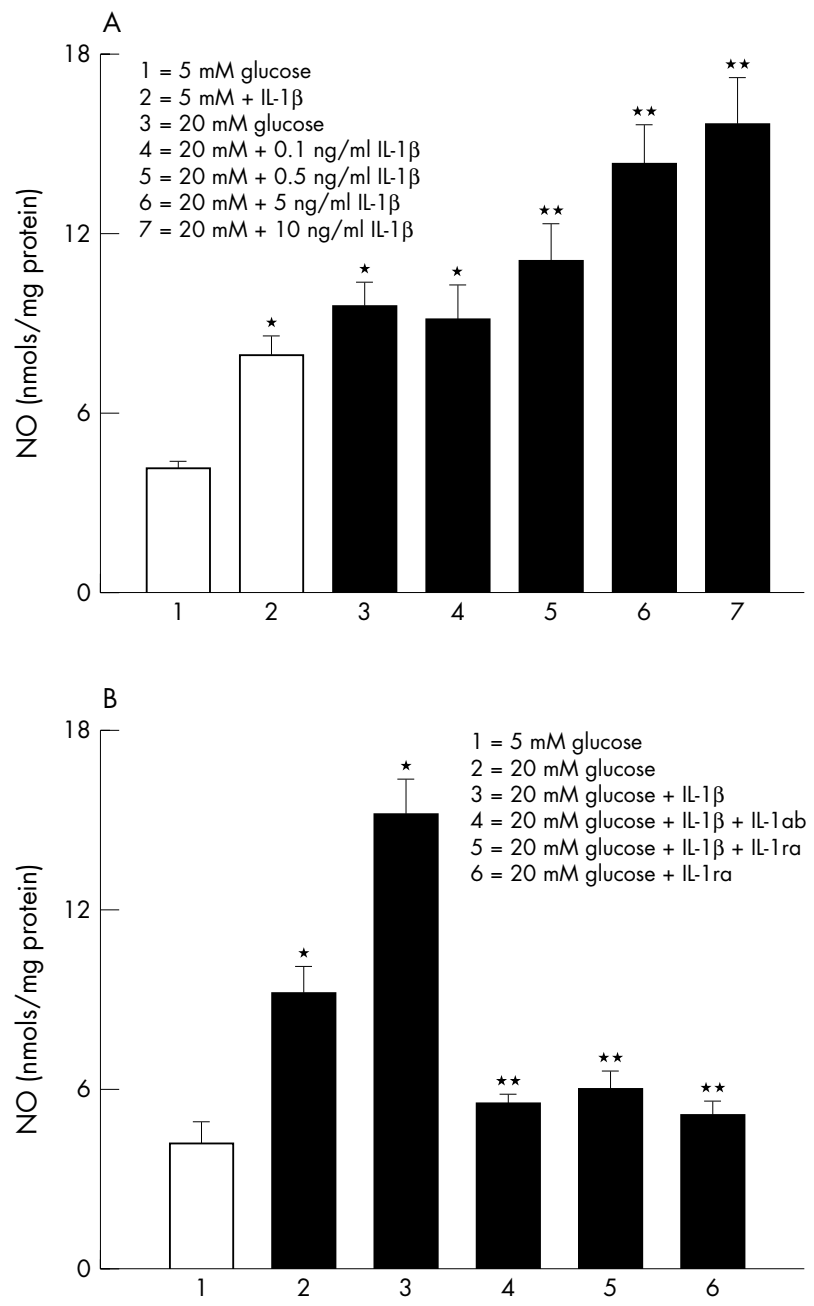

Figure 2 Effect of IL-1 $\beta$ on glucose induced NO in retinal endothelial cells. (A) NO content was measured in the endothelial cells incubated in $5 \mathrm{mM}$ or $20 \mathrm{mM}$ glucose for 3 days in the presence or absence of recombinant IL-1 $\beta$. The data shown are obtained from the cells incubated in $5 \mathrm{mM}$ glucose in the presence of $10 \mathrm{ng} / \mathrm{ml} \mathrm{IL-1 \beta}$, and incubated in $20 \mathrm{mM}$ glucose containing four different concentrations of IL-1 $\beta$. (B) To confirm the effect of IL-1 $\beta$ on glucose induced NO, the cells were also incubated with $50 \mathrm{ng} / \mathrm{ml} \mathrm{IL-1} \mathrm{ab} \mathrm{or} 100 \mathrm{ng} / \mathrm{ml} \mathrm{IL-1 \beta ra} \mathrm{for}$ three days. Each measurement was performed in duplicate. ${ }^{*} \mathrm{p}<0.05$ compared with $5 \mathrm{mM}$ glucose, and ${ }^{* *} p<0.05$ compared with $20 \mathrm{mM}$ glucose.

IL-1 $\beta$ also increased the apoptosis of endothelial cells by $70 \%$, compared with the cells incubated in $5 \mathrm{mM}$ glucose without IL-1 $\beta$ (fig $4 \mathrm{~A}$ ). To further confirm that IL- $1 \beta$ has an important role in the accelerated endothelial cell apoptosis, the effect of IL-1 $\beta$ was determined on the activity of the enzyme important for the execution of apoptosis, caspase- 3 . As shown in figure $4 \mathrm{~B}$, addition of $10 \mathrm{ng} / \mathrm{ml} \mathrm{IL-} 1 \beta$ in $5 \mathrm{mM}$ glucose medium resulted in $40 \%$ increase in the activity of caspase-3.

\section{Effect of IL-1 $\beta$ on high glucose induced NO and cell death}

As reported by us previously, ${ }^{14}{ }^{17}$ incubation of retinal endothelial cells in $20 \mathrm{mM}$ glucose medium for three days increased NO levels by 2.5 fold compared with the cells incubated in $5 \mathrm{mM}$ glucose alone. However, when $20 \mathrm{mM}$ glucose medium was supplemented with $0-10 \mathrm{ng} / \mathrm{nl}$ IL- $1 \beta$, there was a dose dependent increase in NO levels, and the values obtained with $10 \mathrm{ng} / \mathrm{ml} \mathrm{IL-1} \beta$ were almost twofold

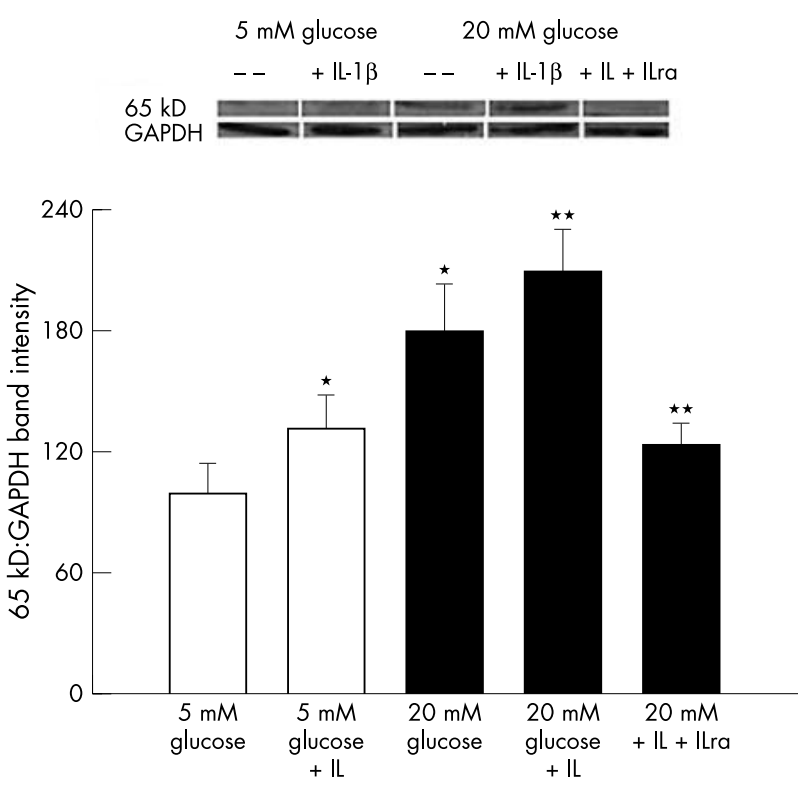

Figure 3 Glucose induced NF- $\mathrm{kB}$ activation and the effect of supplemental IL-1 $\beta$ : western blots were performed for $\mathrm{p} 65$ subunit of NF$\kappa B$ using antibody from Santa Cruz in the cells incubated with or without $10 \mathrm{ng} / \mathrm{ml} \mathrm{IL-1 \beta}$. The band intensities were adjusted to the expression of the intrinsic protein, GAPDH in each sample. The blots are representative of three different cell preparations. ${ }^{*} p<0.05$ and ${ }^{* *} p<0.05$ compared with $5 \mathrm{mM}$ and $20 \mathrm{mM}$ glucose respectively.

higher compared with those obtained from $20 \mathrm{mM}$ glucose alone (fig 2; the concentration of IL-1 $\beta$ used in the subsequent experiments was $10 \mathrm{ng} / \mathrm{ml}$ ). Similarly, IL- $1 \beta$ also increased glucose induced activation of NF- $\kappa B$ by additional $50 \%$ (fig 3).

We have shown that high glucose accelerates the apoptosis of retinal endothelial cells, ${ }^{17}{ }^{19}$ and the results are presented in figure 4 confirming that the incubation of endothelial cells in $20 \mathrm{mM}$ glucose medium for 5 days notably increased their apoptosis by over $90 \%$ compared with that observed from the cells incubated in $5 \mathrm{mM}$ glucose medium. However, addition of IL- $1 \beta$ during the incubation with $20 \mathrm{mM}$ glucose further increased the apoptosis by 2.5 fold (fig 4A), and activated caspase- 3 by additional $30 \%$ compared with the cells incubated in $20 \mathrm{mM}$ glucose medium alone (fig 4B).

\section{Neutralisation of IL- $1 \beta$ and high glucose induced NO and cell death}

In order to confirm that IL-1 $\beta$ plays a crucial role in glucose induced accelerated endothelial cell apoptosis, the effect of neutralisation of IL- $1 \beta$ by IL- lab $(50 \mathrm{ng} / \mathrm{ml}$ monoclonal antibody), or IL-lra $\left(100 \mathrm{ng} / \mathrm{ml}, \mathrm{R} \& \mathrm{D}\right.$ Systems $\left.{ }^{20}\right)$ was determined on the NO levels and cell apoptosis. As shown in figures 2B-4, addition of IL-Ira significantly decreased glucose induced increases in NO levels and NF- $\kappa \mathrm{B}$ expression, and decreased the apoptosis of the retinal endothelial cells. Further, co-incubation of $10 \mathrm{ng} / \mathrm{ml}$ IL- $1 \beta$ with either IL- $1 \mathrm{ab}$ or IL-1ra in $20 \mathrm{mM}$ glucose medium also prevented glucose or IL-1 $\beta$ induced abnormalities and apoptosis in the endothelial cells. The beneficial effects of IL-lab were observed even when the concentration of IL-1 $\beta$ was reduced to $0.5 \mathrm{ng} / \mathrm{ml}$ (data not shown).

\section{DISCUSSION}

This is the first report showing increased levels of inflammatory cytokine, IL-1 $\beta$, in the retinal capillary cells in high glucose conditions, and the effect of IL-1 $\beta$ on their accelerated apoptosis. Our results also show that an 

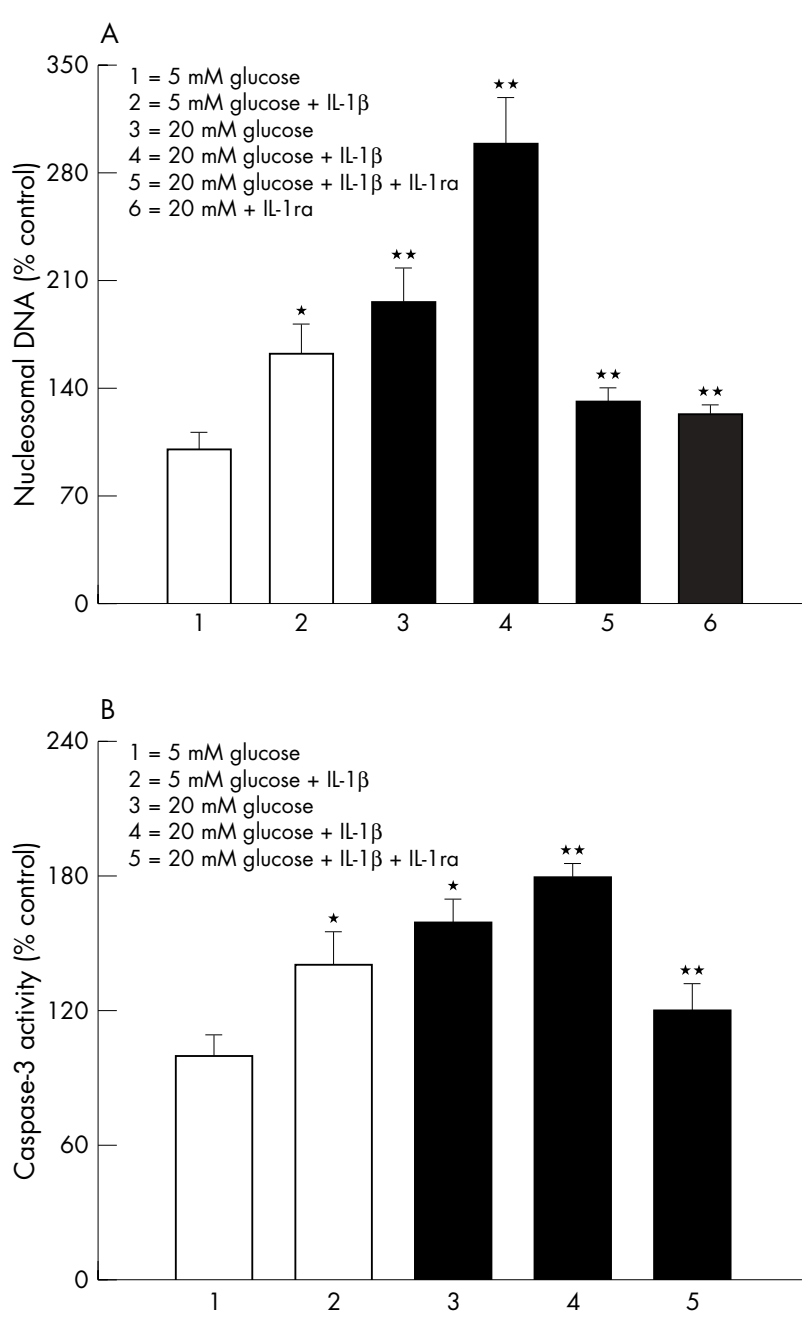

Figure 4 Effect of IL-1 $\beta$ on capillary cell death. (A) Apoptosis was measured by performing ELISA for cytoplasmic histone associated DNA fragments using an assay kit from Roche Diagnostics. The values obtained from the cells incubated in $5 \mathrm{mM}$ glucose are considered $100 \%$. The concentration of IL-1 $\beta$ in the incubation medium was $10 \mathrm{ng} /$ $\mathrm{ml}$, and the incubation time was five days. The values obtained were adjusted to the total DNA. (B) Effect of IL-1 $\beta$ on the activation of apoptosis execution enzyme caspase- 3 was determined in the cells incubated in $5 \mathrm{mM}$ and $20 \mathrm{mM}$ glucose in the presence or absence of $10 \mathrm{ng} / \mathrm{ml} \mathrm{IL-1} \beta$ for 5 days using the fluoregenic substrate DEVD-AFC. The fluorescence signal emitted was quantified at excitation and emission wavelengths of $400 \mathrm{~nm}$ and $505 \mathrm{~nm}$ respectively. Each experiment was repeated with four different cell preparations, and measurements made in duplicate. The values obtained with $5 \mathrm{mM}$ glucose were considered as control values. ${ }^{*} p<0.05$ and ${ }^{* *} p<0.05$ compared with $5 \mathrm{mM}$ and $20 \mathrm{mM}$ glucose, respectively.

accelerated apoptosis of retinal endothelial cells in hyperglycaemia is further increased by IL- $1 \beta$, and the mechanism involves activation of NF- $\kappa \mathrm{B}$, suggesting a role for IL- $1 \beta$ in the development of retinopathy in diabetes. IL- $1 \beta$, a $17 \mathrm{kDa}$ glycoprotein, is produced by a variety of cell types including monocytes, macrophages, lymphocytes, and fibroblasts, and it activates various cells which then release a cascade of inflammatory signals. IL- $1 \beta$ itself is a mediator of intercellular signals within the immune system and between the immune system and other organs. ${ }^{21}$ Here we provide evidence that the levels of this cytokine are increased in the endothelial cells of the retina in diabetic conditions. In support of our results, others have shown increased levels of IL- $1 \beta$ in the vitreous fluid of the patients with proliferative diabetic retinopathy and in the retina from diabetic rats. ${ }^{5-7}$
IL-1 $\beta$ can induce the expression of many genes whose promoters are regulated through complex interactions with $\mathrm{NF}-\kappa \mathrm{B} .{ }^{11}{ }^{12} \mathrm{NF}-\kappa \mathrm{B}$, heterodimer with two subunits, p50 and p65, is regulated by redox control mechanisms, and transcriptionally activates various cellular genes involved in immune response, inflammation, and oxidative stress. ${ }^{22-24}$ It is localised in the subretinal membranes and in the microvessels, ${ }^{25}$ and is usually stored in its inactive form in the cytosol. Following IL-1 $\beta$ stimulation, it is translocated into the nucleus where it initiates the transcription of many genes involved in apoptosis. We have shown that NF- $\mathrm{\kappa B}$ is activated in the retina in diabetes and in the capillary cells of the retina in high glucose conditions. Our studies have suggested that the activation of NF- $\mathrm{KB}$ is an early event in the development of retinopathy, that is sustained when the retinal capillary cell death is accelerating and histopathology is developing. ${ }^{14}$ Further, the activation of NF- $\kappa \mathrm{B}$ seems to be associated with the failure of retinopathy to arrest after reestablishment of normal glycaemia (Knowluru RA, et al.

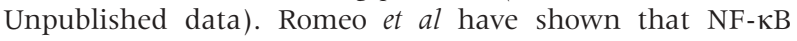
activation in retinal pericytes plays a significant role in the hyperglycaemia induced accelerated loss of pericytes observed in diabetic retinopathy. ${ }^{13}$ Data are provided here showing that IL- $1 \beta$ activates NF- $\kappa B$ in the retinal endothelial cells that is amplified in high glucose conditions, and suggest that in diabetes IL-1 $\beta$ might play an important role in the activation of NF- $\mathrm{KB}$ and its signalling pathways.

In retina IL- $1 \beta$ gene expression is present in glial cells and endothelial cells, and the expression is significantly upregulated in the glial cells, endothelial cells, and neutrophils recruited into the retina during reperfusion after induced retinal ischaemia. ${ }^{8}$ Administration of IL- $1 \beta$ into the vitreous of Lewis rats is reported to cause retinal inflammatory response that is accompanied by the breakdown of the vascular blood retinal barrier. This induces the recruitment of leukocytes that enter the retina predominantly through the retinal vasculature, and migrate through retinal endothelial cells, suggesting that IL- $1 \beta$ is an important factor in the pathogenesis of human retinal inflammation. ${ }^{26}$ IL- $1 \beta$ leads to the induction of vascular endothelial growth factor in vascular smooth muscle cells. ${ }^{26}$ Similar abnormalities are observed in the retina in diabetes; the capillaries in the retina become non-perfused, obliterated and ischaemic, ${ }^{27}$ VEGF levels are increased, ${ }^{28}$ and the number of platelet fibrin thrombi increases. ${ }^{29}$ These proinflammatory changes and leukostasis are some of the earliest changes observed in the retina of diabetic animals, ${ }^{30}$ and administration of aspirin, an anti-inflammatory compound, inhibits the development of retinopathy in diabetic dogs, ${ }^{31}$ suggesting that this inflammatory cytokine might play an important role in the pathogenesis of diabetic retinopathy.

Retinal capillary cells are shown to undergo accelerated cell death in the pathogenesis of diabetic retinopathy, and apoptosis has been implicated as one of the mechanism(s) in their accelerated death. ${ }^{32}$ Apoptotic cells themselves can become procoagulant, and that can create a proinflammatory environment. ${ }^{10}$ The levels of proapoptotic protein Bax are higher in the capillary cells of the retina. ${ }^{13}{ }^{17}$ We have shown that the activity of caspase- 3 is increased in the rat retina at duration of diabetes when capillary cell death and histopathology can be detected. ${ }^{16}$ IL-1 $\beta$ has been shown to induce apoptosis in retinal neuronal cells during reperfusion ischaemia, ${ }^{33}$ and this supports our results showing that IL$1 \beta$ exerts proapoptotic effects on retinal endothelial cells that are aggravated in high glucose conditions.

IL- $1 \beta$ is considered as one of the most potent stimuli for inducible form of nitric oxide synthase (iNOS), and it stimulates NO production by a dual pathway-that is, by the transcriptional induction of iNOS protein and by the 
augmentation of iNOS activity. ${ }^{34}$ In diabetic conditions iNOS and NO levels are increased in the retina and its capillary cells, ${ }^{1415} 17$ and others have shown that in rat aortic rings, high glucose enhances the IL-1 $\beta$ induced NO. ${ }^{35}$ The present study provides strong evidence that increased IL-1 $\beta$ in the retinal endothelial cells contributes to the increased levels of $\mathrm{NO}$ and apoptosis seen in the retina and its capillary cells in diabetes. It has been shown that IL- $1 \beta$ is not neurotoxic directly to healthy neurons, or to normal rodent brain, but injection of low doses of IL-1 $\beta$ into the cerebral ventricles exposed to other insults notably exacerbates the damage. ${ }^{36}$ Our results clearly show that under diabetic conditions increased IL-1 $\beta$ significantly increases the glucose induced damage of retinal capillary cells.

The receptor antagonists of IL-1 $\beta$ are believed to block all actions of IL- $1 \beta$ without exerting any other actions. ${ }^{20}$ We have provided convincing data that IL-Ira notably and reproducibly protects against glucose induced increase in $\mathrm{NO}$ and apoptosis in retinal endothelial cells. Taken together, these results suggest that the increased inflammatory IL- $1 \beta$ and high glucose are, perhaps, acting together during the course and progression of diabetic retinopathy. Our studies offer a possible rationale to test IL- $1 \beta$ receptor antagonists (already being tested for inflammatory and immune disorders) to inhibit the development of diabetic retinopathy.

\section{ACKNOWLEDGEMENTS}

The authors thank Saiyeda N Abbas for technical assistance. This study was supported in part by grants from Juvenile Diabetes Research Foundation, The Thomas Foundation, and Research to Prevent Blindness.

\section{Authors' affiliations}

R A Kowluru, S Odenbach, Kresge Eye Institute, Wayne State University, Detroit, MI, USA

\section{REFERENCES}

1 Kador PF, Akagi Y, Terubayashi H, et al. Prevention of pericyte ghost formation in refinal capillaries of galactose-fed dogs by aldose reductase inhibitors. Arch Ophthalmol 1998;106:1099-102.

2 Xia P, Inoguchi T, Kern TS, et al. Characterization of the mechanism for the chronic activation of DAG-PKC pathway in diabetes and hypergalactosemia. Diabetes 1994;43:1122-9.

3 Stitt AW, Li YM, Gardiner TA, et al. Intracellular advanced glycation endproducts (AGEs) co-localize with AGE-receptors in the retinal vasculature of diabetic and AGE-infused rats. Am J Pathol 1997;150:523-31.

4 Kowluru RA, Tang J, Kern TS. Abnormalities of retinal metabolism in diabetes and experimental galactosemia. VII. Effect of long-term administration of antioxidants on the development of retinopathy. Diabetes 2001;50:1938-42.

5 Abu el Asrar AM, Maimone D, Morse PH, et al. Cytokines in the vitreous of patients with proliferative diabetic retinopathy. Am J Ophthalmol 1992;114:731-6.

6 Yuuki T, Kanda T, Kimura Y, et al. Inflammatory cytokines in vitreous fluid and serum of patients with diabetic vitreoretinopathy. J Diabetes Complications 2001; 15:257-9.

7 Carmo A, Cunha-Vaz JG, Carvalho AP, et al. L-arginine transport in retinas from streptozotocin diabetic rats: correlation with the level of IL-1 $\beta$ and NO synthase activity. Vision Res 1999;39:3817-23.

8 Hangai M, Yoshimura N, Yoshida M, et al. Interleukin-1 gene expression in transient retinal ischemia in the rat. Invest Ophthalmol Vis Sci 1995; 36:571-8.

9 Mizutani M, Kern TS, Lorenzi M. Accelerated death of retinal microvascular cells in human and experimental diabetic retinopathy. J Clin Invest 1996;97:2883-90.
10 Hébert M-J, Gullans SR, Mackenzie HS, et al. Apoptosis of endothelial cells is associated with paracrine induction of adhesion molecules: evidence for an interleukin-1 $\beta$-dependent paracrine loop. Am J Pathol 1998; 15:523-32.

11 Lenardo MJ, Baltimore D. NF- $\kappa$ B: a pleiotropic mediator of inducible and tissue-specific gene control. Cell 1989;58:227-9.

12 Baeuerle PA. The inducible transcription activator NF- $\kappa$ B: regulation by distinct protein subunits. Biochim Biophys Acta 1991;1072:63-80.

13 Romeo G, Liu WH, Asnaghi V, et al. Activation of nuclear factor- $\kappa B$ induced by diabetes and high glucose regulates a proapoptotic program in retinal pericytes. Diabetes 2002;51:2241-8

14 Kowluru RA, Koppolu P, Chakrabarti S, et al. Diabetes-induced activation of nuclear transcriptional factor in the retina, and its inhibition by antioxidants. Free Radic Res 2003;37:1 169-80.

15 Kowluru RA. Diabetes-induced elevations in retinal oxidative stress, protein kinase $C$ and nitric oxide are inter-related. Acta Diabetologica 2001;38:179-85

16 Kowluru RA, Koppolu P. Diabetes-induced activation of Caspase-3 in retina: Effect of antioxidant therapy. Free Radic Res 2002;36:993-9.

17 Kowluru RA, Abbas SN. Diabetes-induced mitochondrial dysfunction in the retina. Inves Ophthal Vis Sci 2003;44:5327-34.

18 Tannous M, Veluthakal R, Amin R, et al. IL-1 induced nitric oxide release from insulin-secreting beta cells: Further evidence for the involvement of GTPbinding proteins. Diabetes Metab 2002;28:S78-84.

19 Kowluru RA, Kowluru A, Chakrabarti S, et al. Potential contributory role of $\mathrm{H}$ Ras, a small G-protein, in the development of retinopathy in diabetic rats. Diabetes 2003;53:775-83.

20 Beauregard C, Brandt PC, Chiou GC. Induction of nitric oxide synthase and over-production of nitric oxide by interleukin- $1 \beta$ in cultured lacrimal gland acinar cells. Exp Eye Res 2003;77:109-14.

21 Meacock WR, Spalton DJ, Stanford MR. Role of cytokines in the pathogenesis of posterior capsule opacification. Br J Ophthalmol 2000;84:332-6.

22 Urata Y, Yamamoto H, Goto S, et al. Long exposure to high glucose concentration impairs the responsive expression of gamma-glutamylcysteine synthetase by interleukin-1 $\beta$ and tumor necrosis factor-alpha in mouse endothelial cells. J Biol Chem 1996;271:15146-52.

23 Teng X, Zhang H, Snead C, et al. Molecular mechanisms of iNOS induction by IL-1 $\beta$ and IFN $-\gamma$ in rat aortic smooth muscle cells. Am J Physiol Cell Physiol 2002;282:C144-52.

24 Du X, Stocklauser-Farber K, Rosen P. Generation of reactive oxygen intermediates, activation of NF- $\kappa B$, and induction of apoptosis in human endothelial cells by glucose: role of nitric oxide synthase? Free Radic Biol Med 1999;27:752-63.

25 Hammes HP, Hoerauf $\mathrm{H}$, Alt A, et al. N(epsilon) (carboxymethyl) lysin and the AGE receptor RAGE colocalize in age-related macular degeneration. Invest Ophthalmol Vis Sci 1999;40:1855-9

26 Jung YD, Liu W, Reinmuth N, et al. Vascular endothelial growth factor is upregulated by interleukin-1 $\beta$ in human vascular smooth muscle cells via the P38 mitogen-activated protein kinase pathway. Angiogenesis $2001 ; 4: 155-62$.

27 Engerman RL. Pathogenesis of diabetic retinopathy. Diabetes 1989:38:1203-6.

28 Duh E, Aiello LP. Vascular endothelial growth factor and diabetes: the agonist versus antagonist paradox. Diabetes 1999;48:1899-906.

29 Boeri D, Maiello M, Lorenzi M. Increased prevalence of microthromboses in retinal capillaries of diabetic individuals. Diabetes 2001:50:1432-9.

30 Miyamoto K, Khosrof S, Busell SE, et al. Prevention of leukostasis and vascular leakage in streptozotocin-induced diabetic retinopathy via intercellular adhesion molecule-1 inhibition. Proc Natl Acad Sci 1999;96:10836-41.

31 Kern TS, Engerman RL. Pharmacological inhibition of diabetic retinopathy: aminoguanidine and aspirin. Diabetes 2001;50:1636-42

32 Kern TS, Tang J, Mizutani M, et al. Response of capillary cell death to aminoguanidine predicts the development of retinopathy: Comparison of diabetes and galactosemia. Invest Ophthal Vis Sci 2000:41:3972-8.

33 Zhou Y, Lindner LE, Chiou GC, et al. Transient retinal ischemia-reperfusion in rats. Chin Med J 2000;1 13:461-5.

34 Ueda S, Kato S, Matsuoka H, et al. Regulation of cytokine-induced nitric oxide synthesis by asymmetric dimethylarginine: Role of dimethylarginine dimethylaminohydrolase. Circ Res 2003;92:226-33.

35 Morales J, Dunbar JC, Ram JL. Effect of aldose reductase inhibition on interleukin-1 $\beta$-induced nitric oxide (NO) synthesis in vascular tissue. Int J Exp Diabetes Res 2002:3:11-20.

36 Rothwell N. Interleukin-1 and neuronal injury: mechanisms, modification, and therapeutic potential. Brain Behav Immun 2003;17:152-7. 